\title{
KAJIAN KONDISI ATMOSFER DI WILAYAH INDONESIA SAAT PERIODE AKTIFNYA BADAI TROPIS KAI-TAK
}

\author{
Prabu Aditya Sugianto ${ }^{1}$, Mukhamad Adib Azka ${ }^{2}$, Reynold Mahubessy ${ }^{3}$, Paulus Agus \\ Winarso ${ }^{4}$
}
1,2,3. Program Studi DIV Meteorologi, Sekolah Tinggi Meteorologi Klimatologi dan Geofisika, Jl. Perhubungan I No. 5, Pondok Betung, Pondok Aren, Pd. Betung, Tangerang Selatan, Kota Tangerang Selatan, Banten 152212

4. Dosen Program Studi DIV Meteorologi, Sekolah Tinggi Meteorologi Klimatologi dan Geofisika, Jl. Perhubungan I No. 5, Pondok Betung, Pondok Aren, Pd. Betung, Tangerang Selatan, Kota Tangerang Selatan, Banten 152212

Email : prabuadityasugianto@gmail.com

\begin{abstract}
Tropical cyclone are weather phenomena that hardly occur in Indonesia, but their effects can affect atmospheric conditions in the Indonesian region, especially in areas near its growth. One of the tropical cyclone that occurred near the territory of Indonesia is Kai-tak tropical cyclone. Kai-tak tropical cyclone occurred on December 13-22, 2017 in Philippine waters. In this study, atmospheric conditions in the Indonesian region will be examined during the Kaitak tropical cyclone. The data used in this study are ECMWF reanalysis model data (European Center for Medium Weather Forecast) in the form of vorticity data, Moisture Transport, and wind speed and direction, and also satellite data, namely Himawari-8 satellite IR-1 channel for viewing distribution. spatial cloud propagation index occurring as well as the Global Satellite Mapping of Precipitation (GSMaP) satellite to see the spatial distribution of rainfall as a result of Kai-tak tropical cyclone. The results showed that in the period December 13-16 2017, in the northern part of Sulawesi, the eastern part of Kalimantan Island, the northern region of Sulawesi Island to the northern part of Halmahera Island and parts of Southern Sumatra and Java were indirectly affected by tropical storms Kai -not where Kai-tak tropical storms cause light to moderate intensity rainfall in the region. Whereas in the period of 17-22 December 2017 where the weak tropical storms (tropical depression) rainfall that occurred in most parts of Indonesia occurred due to the spread of air masses from Asia.
\end{abstract}

Keywords: tropical cyclone, atmospheric conditions, impacts

Abstrak: Badai tropis merupakan fenomena cuaca yang hampir tidak terjadi di Indonesia, tetapi
dampaknya dapat mempengaruhi kondisi atmosfer di wilayah Indonesia khususnya di wilayah dekat
pertumbuhannya. Salah satu badai tropis yang terjadi di dekat wilayah Indonesia yaitu badai tropis
Kai-tak. Badai tropis Kai-tak terjadi pada periode $13-22$ Desember 2017 di perairan Filipina. Pada
penelitian ini akan dikaji kondisi atmosfer di wilayah Indonesia pada saat terjadinya badai tropis
Kaitak. Data yang digunakan dalam penelitian ini yaitu data model reanalysis ECMWF (European
Centre for Medium Weather Forecast) berupa data vortisitas, Moisture Transport, serta arah dan
kecepatan angin, Selain itu digunakan juga data satelit yaitu satelit Himawari-8 kanal IR-1 untuk
melihat distribusi spasial indeks konvektif sebaran awan yang terjadi serta satelit Global Satellite
Mapping of Precipitation (GSMaP) untuk melihat distribusi spasial curah hujan sebagai dampak dari
badai tropis Kai-tak. Hasil penelitian menunjukkan bahwa pada periode 13-16 Desember 2017 , di
wilayah Sulawesi bagian utara,wilayah Pulau Kalimantan bagian timur,wilayah utara Pulau Sulawesi
hingga wilayah utara Pulau Halmahera serta sebagian Sumatera bagian Selatan dan Pulau Jawa
terkena dampak secara tidak langsung dari badai tropis Kai-tak dimana badai tropis Kai-tak
mengakibatkan hujan dengan intensitas ringan hingga sedang di wilayah tersebut. Sedangkan pada 
periode 17-22 Desember 2017 dimana badai tropis melemah (tropical depression) curah hujan yang terjadi di sebagian besar wilayah Indonesia terjadi akibat adanya penjalaran massa udara dari Asia.

Kata kunci: badai tropis, kondisi atmosfer,dampak

\section{PENDAhULUAN}

Letak Indonesia yang diapit dua samudera (Hindia dan Pasifik) serta dua benua (Asia dan Australia) menjadikan cuaca di Indonesia juga dipengaruhi oleh kondisi atmosfer di dua benua dan samudera tersebut,selain tentu dipengaruhi oleh kondisi atmosfer lokalnya sendiri . Salah satu fenomena cuaca diluar wilayah Indonesia yang menyebabkan variabilitas cuaca adalah badai tropis (tropical cyclone).

Badai tropis (tropical cyclone) adalah suatu sistem tekanan rendah yang berkembang di atas lautan luas dengan kecepatan angin maksimum 34 knot atau lebih yang mendominasi di sekitar pusatnya dan telah bertahan setidaknya selama 6 jam (Zakir,2006). Sebutan badai tropis ini berbeda-beda di setiap wilayah di seluruh dunia. Di Atlantik dan Pasifik timur disebut Hurricane, di Pasifik Barat disebut Typhoon, di Samudera Hindia disebut Cyclone.

Dampak adanya badai tropis diantaranya menyebabkan adanya cuaca ekstrem seperti hujan lebat,angin kencang dan lain-lain. Dampak yang diakibatkan badai tropis ini bergantung pada skala intensitas kekuatannya. Skala intensitas yang umumnya digunakan sebagai pedoman dalam menentukan suatu badai tropis umumnya menggunakan skala yang disebut skala Saffir-Simpsons. Skala Saffir-Simpsons membagi skala badai tropis berdasarkan kecepatan pusaran angina dan tekanan atmosfer pada badai (Choir,2011). Berikut adalah skala badai tropis berdasarkan skala Saffir-Simpsons.

Tabel 1. Skala Saffir Simpsons

\begin{tabular}{|c|c|c|c|c|c|c|c|}
\hline Type & Category & Damage & $\begin{array}{l}\text { Winds } \\
\text { (knots) }\end{array}$ & $\begin{array}{l}\text { Winds } \\
(\mathbf{k m} / \mathbf{h})\end{array}$ & $\begin{array}{l}\text { Winds } \\
\text { (mph) }\end{array}$ & $\begin{array}{c}\text { Surge } \\
\text { (m) }\end{array}$ & $\begin{array}{l}\text { Surge } \\
\text { (ft) }\end{array}$ \\
\hline Depression & TD & & $<34$ & $<63$ & $<39$ & & \\
\hline $\begin{array}{l}\text { Tropic al } \\
\text { Sto m }\end{array}$ & TS & & $34-63$ & $63-117$ & $39-73$ & & \\
\hline $\begin{array}{c}\text { Hurric ane/ } \\
\text { Typhoon }\end{array}$ & 1 & Minimal & $64-82$ & $118-152$ & $74-95$ & $\begin{array}{l}1.2- \\
1.5 \\
\end{array}$ & $4 \cdot 5$ \\
\hline $\begin{array}{c}\text { Hurricane/ } \\
\text { Typhoon }\end{array}$ & 2 & Moderate & $83-95$ & $153-176$ & $96-110$ & $\begin{array}{l}1.8- \\
2.4 \\
\end{array}$ & $6-8$ \\
\hline $\begin{array}{c}\text { Hurricane/ } \\
\text { Typhoon }\end{array}$ & 3 & Exte nsive & $96-112$ & $177-208$ & $\begin{array}{c}111 \cdot \\
130 \\
\end{array}$ & $\begin{array}{l}2.7- \\
3.6 \\
\end{array}$ & $9 \cdot 12$ \\
\hline $\begin{array}{l}\text { Hurric ane/ } \\
\text { Typhoon }\end{array}$ & 4 & Extre me & 113-135 & 209-248 & $\begin{array}{l}131- \\
155\end{array}$ & $\begin{array}{l}3.9- \\
5.4\end{array}$ & $13-18$ \\
\hline $\begin{array}{l}\text { Hurric ane/ } \\
\text { Tvnhoon }\end{array}$ & 5 & Cata strophic & $>135$ & $>248$ & $>155$ & $>5.4$ & $>18$ \\
\hline
\end{tabular}

Pada penelitian ini dilakukan kajian terhadap badai tropis Kai-tak. Berdasarkan pembagian skala Saffir-Simpson diatas maka skala intensitas kekuatan dari badai tropis Kai-tak pada periode kejadian dapat dikategorikan sebagai badai tropis yang umumnya berada pada tingkat tropical storm, sedangkan pada saat melemah badai tropis akan berada pada tingkat tropical depression, yang dapat dilihat pada tabel berikut : 
Tabel 2. Tingkat skala intensitas kekuatan badai tropis Kai-tak

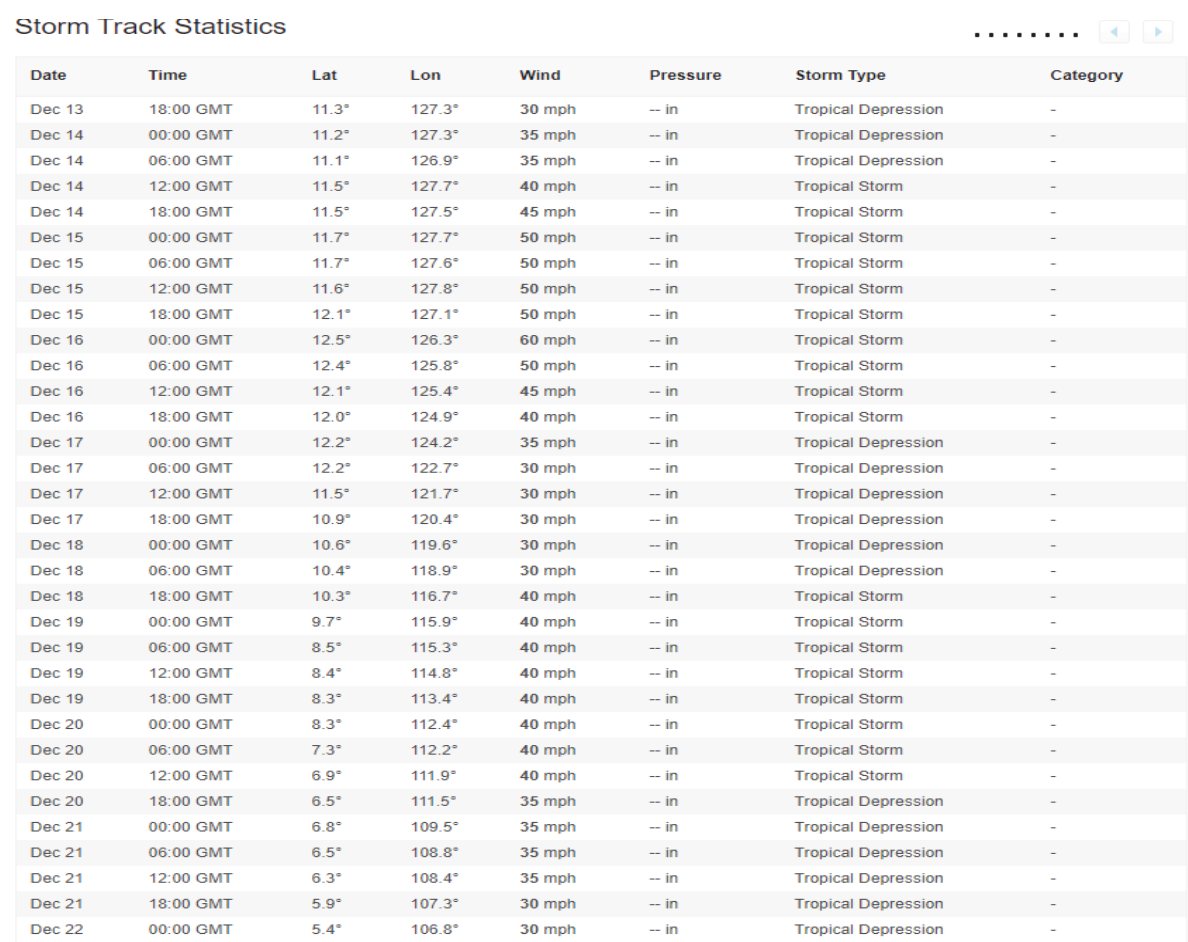

Badai tropis Kai-tak muncul di perairan Filipina pada periode 13-22 Desember 2017 dengan pergerakan ke arah barat daya wilayah Filipina menuju wilayah perairan Laut China Selatan disebelah utara wilayah pulau Kalimantan (Gambar 1). Untuk itu akan dilakukan kajian sejauh mana badai tropis Kai-tak tersebut mempengaruhi kondisi atmosfer di wilayah Indonesia.

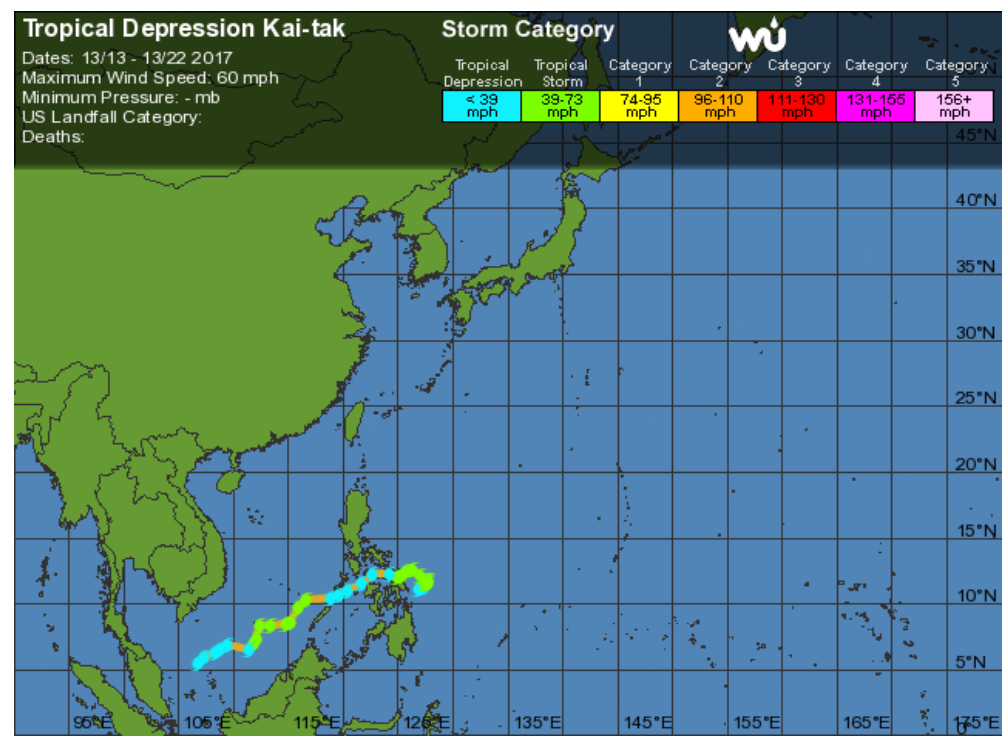

Gambar 1. Trajektori pergerakan badai tropis Kai-tak 


\section{DATA DAN METODE PENELITIAN}

\subsection{Data Penelitian}

Data penelitian yang digunakan dalam penelitian ini adalah data model reanalysis ECMWF, data satelit GSMaP, dan data satelit Himawari-8 mulai tanggal 13-22 Desember 2017. Berikut rincian data parameter yang diambil dalam penelitian ini adalah sebagai berikut:

a. Data Moisture Transport didapat dari olahan data reanalysis ECMWF tiap lapisan yaitu spesifik humidity,angin $\mathrm{u}$ dan angin $\mathrm{v}$. Data-data tersebut kemudian diolah mrnggunakan persamaan analisis pergerakan vertical Moisture Transport (Xiaoxia,2010). Persamaan tersebut adalah sebagai berikut :

$$
\boldsymbol{Q}=\frac{1}{g} \int_{300}^{p_{s}}(\boldsymbol{V} q) \mathrm{d} p .
$$

Keterangan : Q ; Moisture Transport vertical

g: Percepatan gravitasi $\left(\mathrm{m} / \mathrm{s}^{-2}\right)$

q: specific humidity $\left(\mathrm{kg} / \mathrm{ms}^{-1}\right)$

p: $\operatorname{pressure}(\mathrm{mb})$

$\mathrm{V}$ : Angin vector dua dimensi: angin zonal dan angin meridional $(\mathrm{m} / \mathrm{s})$

b. Data estimasi curah hujan dari satelit GSMaP (Global Satellite Mapping of

Precipitation) dengan resolusi $0.1^{\circ} \times 0.1^{\circ}$ pada saat periode terjadinya badai tropis

Kai-tak.

c. Data satelit Himawari-8 kanal IR digunakan untuk mencari nilai indeks konvektif (ik) berdasarkan persamaan Sakurai (2005) yaitu sebagai berikut ;

0 - Tb untuk $\mathrm{Tb}<230 \mathrm{~K}$

0 untuk $\mathrm{Tb}>230 \mathrm{~K}$

Keterangan : ik: nilai indeks konvektif

Tb: nilai brightness temperature $[\mathrm{K}]$

$\mathrm{K}$ : Satuan temperature dalam Kelvin

\subsection{Metode Penelitian}

Metode penelitian yang digunakan dalam penelitian ini adalah analisis deskriptif terhadap visualisasi dari data-data parameter yang diolah pada data penelitian.Dalam melakukan visualisasi data digunakan software GrADS (The Grid Analysis and Display System). 


\section{Hasil dan Pembahasan}

\subsection{Analisis Indeks Konvektif}

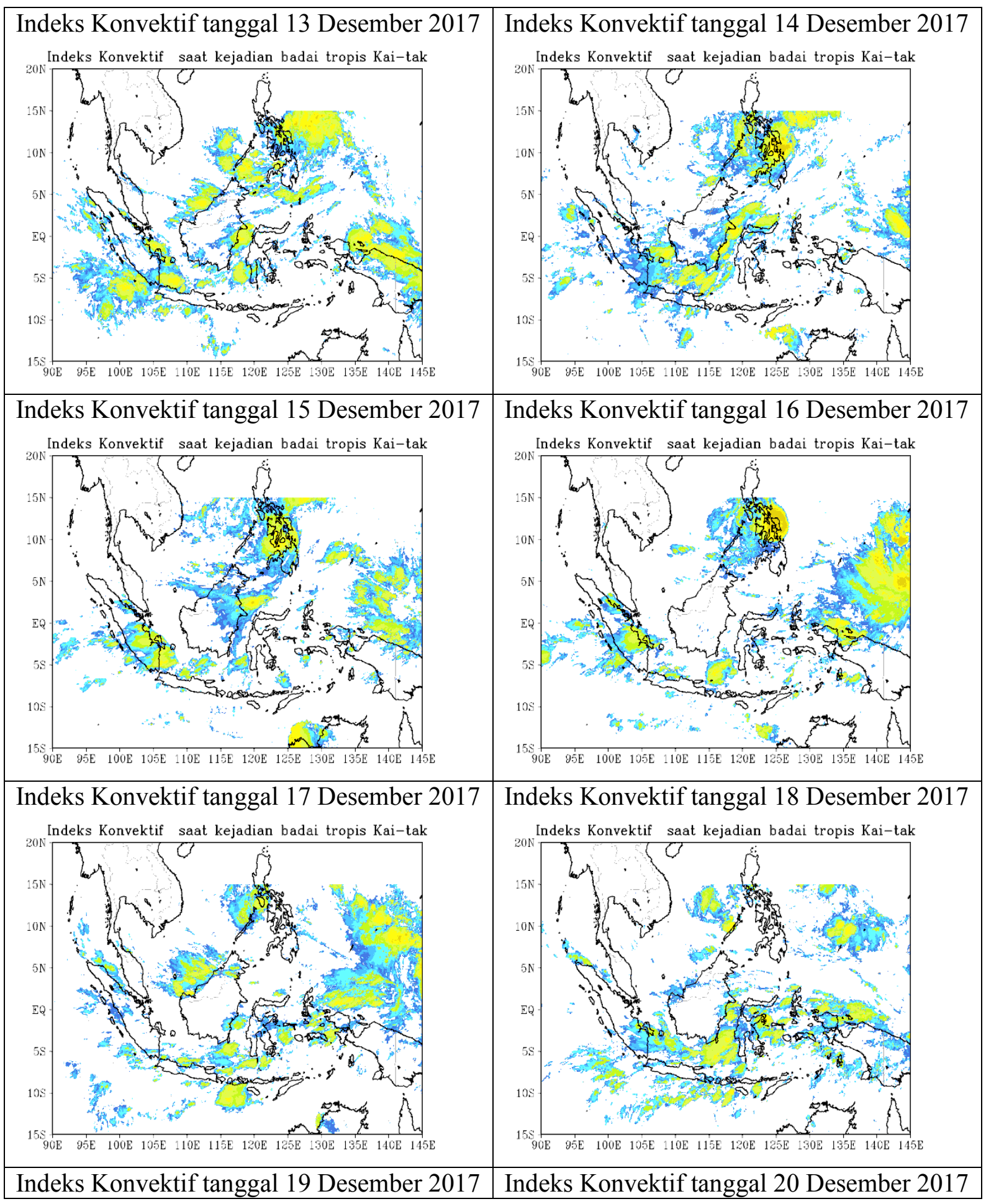




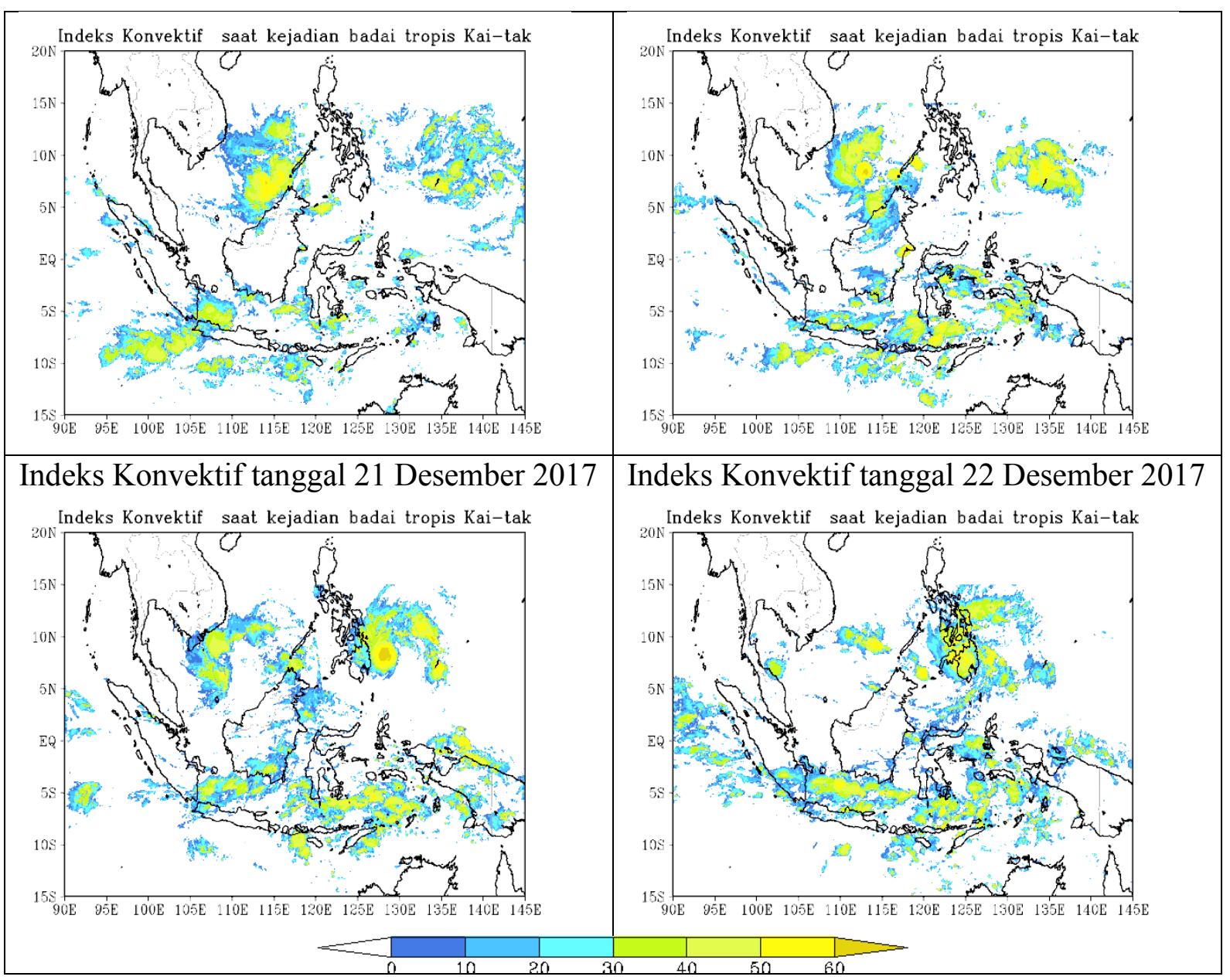

Gambar 3. Indeks konvektif saat kejadian badai tropis Kai-tak 13 - 22 Desember 2017

Berdasarkan hasil olahan data satelit Himawari-8 kanal IR yang menghasilkan Indeks konvektif, dapat dilihat adanya pergerakan awan-awan konvektif yang membentuk lingkaran dari wilayah timur perairan Filipina menuju perairan utara wilayah Pulau Kalimantan dari tanggal 13 Desember 2017-16 Desember 2017. Awan -awan konvektif tersebut terdeteksi memiliki nilai indeks konvektif 40-50. Selain itu, dari gambar diatas juga dapat dilihat bahwa badai tropis Kai-tak juga menyebabkan banyaknya pumpunan awan akibat adanya daerah konvergensi yang diakibatkan badai tropis Kai-tak dengan nilai indeks konvektif berkisar antara 20-40 di sebagian besar wilayah Indonesia.Luasan wilayah dengan aktivitas konvektif yang tinggi dapat menunjukkan luasan wilayah pembentukan awan-awan konvektif (awan CB) yang diidentifikasi sebagai daerah terjadinya hujan (Saragih.dkk,2018). Hal inilah yang memicu peluang banyaknya kejadian cuaca ekstrem seperti hujan lebat, angin kencang,dan lain-lain. Pada periode 13-16 Desember 2017 inilah badai tropis Kai-tak ada pada tingkat tropical storm.

Pada tanggal 17-22 Desember 2017 aktivitas badai tropis Kai-tak melemah ke tingkat tropical depression. Dari gambar diatas dapat dilihat pada tanggal 17-18 Desember sebaran dan intensitas nilai indeks konvektif berkurang, namun pada hari berikutnya yaitu tanggal 1922 Desember 2017 terlihat sebaran dan nilai indeks konvektif kembali mulai meningkat, namun ini lebih dikarenakan pengaruh adanya massa udara dingin dari Asia yang masuk ke wilayah laut China Selatan sedangkan untuk pengaruh badai tropis Kai-tak sangat kecil 
karena pada periode tersebut badai tropis Kai-tak ada dalam tingkat tropical depression yang hampir punah.

\subsection{Analisis Moisture Transport}

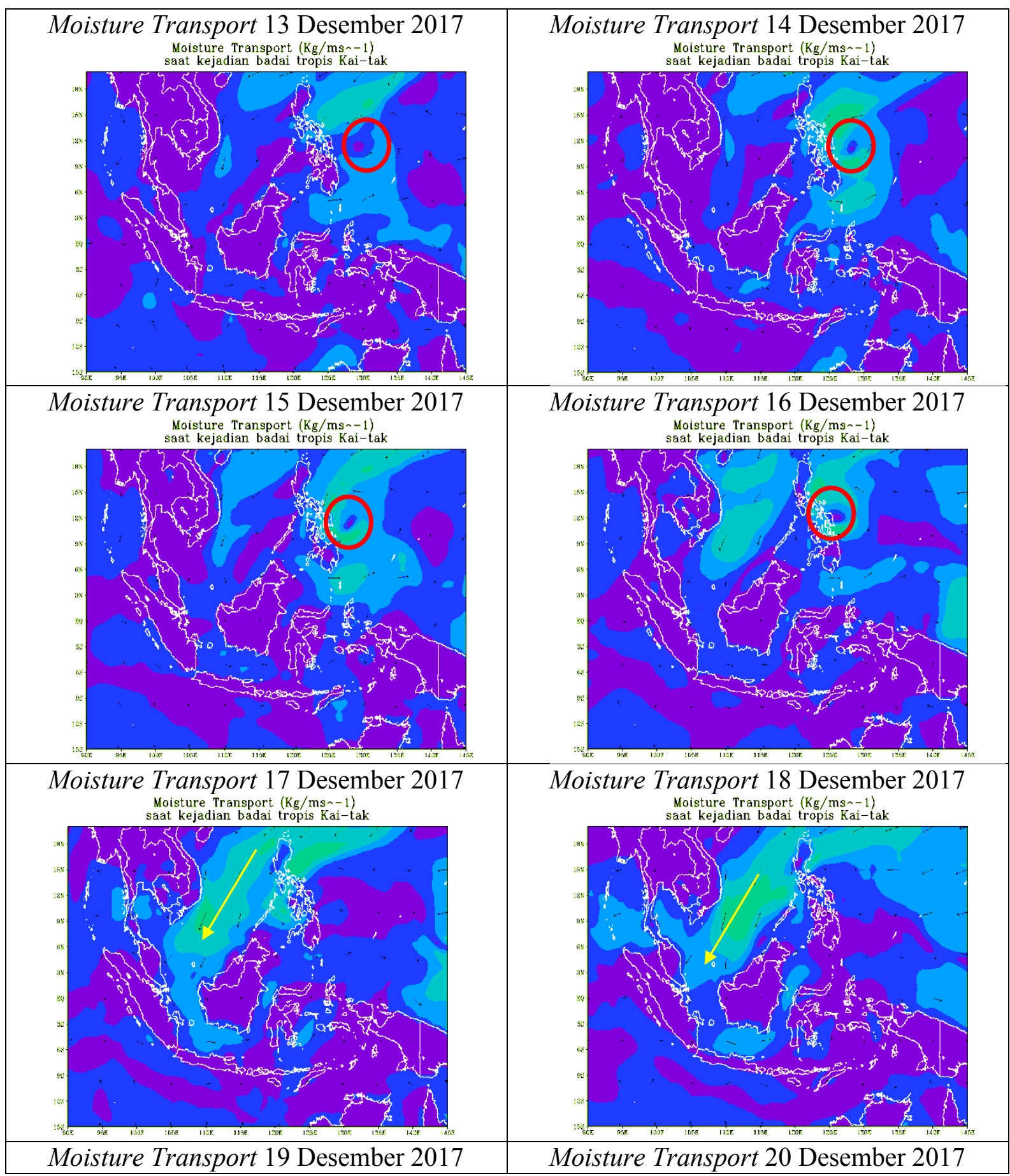




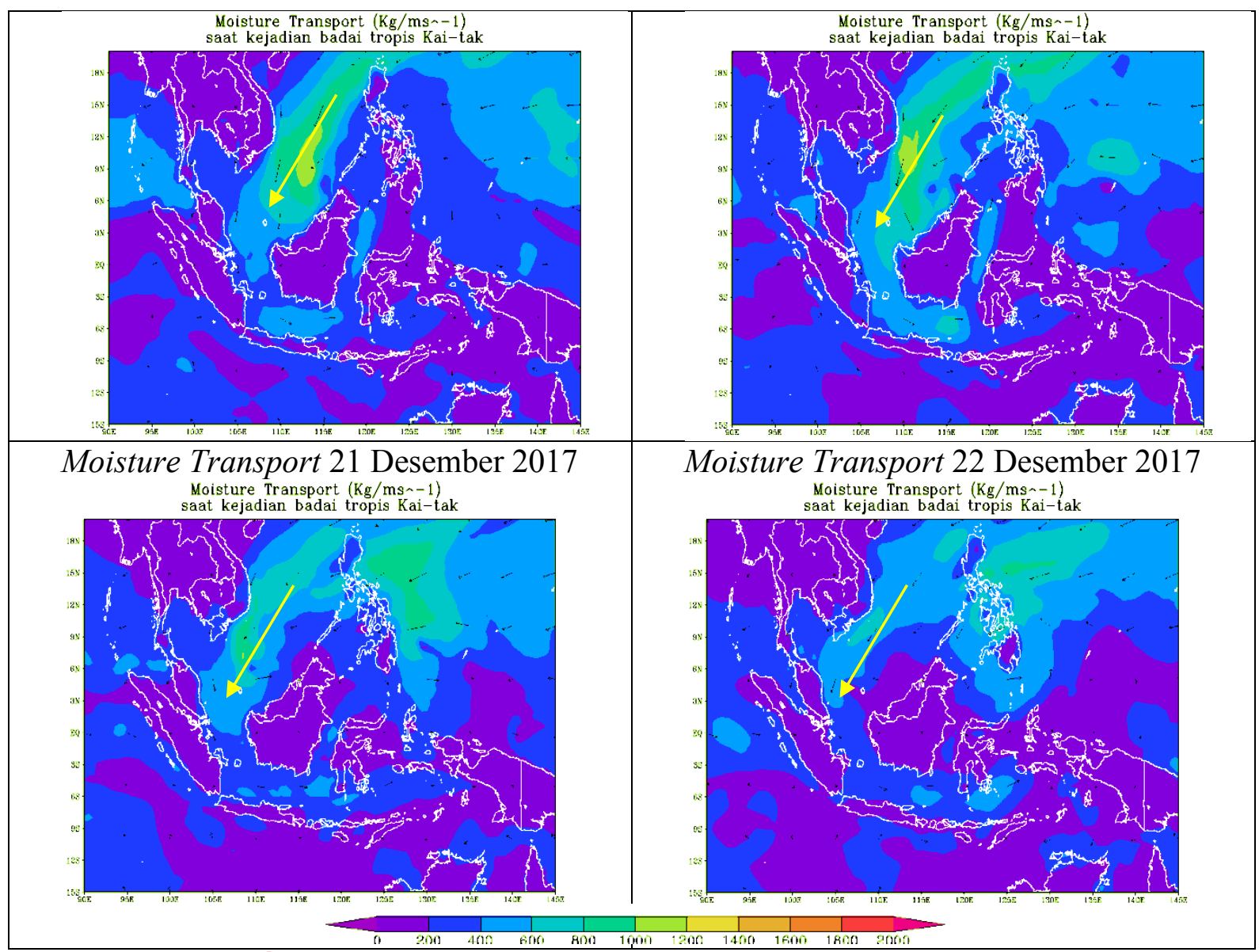

Keterangan : $\mathrm{O}$ : badai tropis Kai-tak

: Massa udara dari Asia

Gambar 4. Moisture Transport saat kejadian badai tropis Kai-tak 13 - 22 Desember 2017

Berdasarkan hasil olahan data ECMWF berupa moisture transport dan arah angin menggunakan aplikasi Grads, menunjukan adanya jumlah massa uap air yang cukup tinggi pada wilayah timur Filipina. Massa uap air ini kemudian menjalar dari tanggal 13 Desember 2017 sampai 16 Desember 2017 dengan nilai jumlah massa uap air 600-1200 kg m/s. Massa uap air ini bergerak menuju ke arah Barat melintasi wilayah Filipina dan kemudian melemah di sekitar wilayah perairan utara Pulau Kalimantan. Pada periode ini, badai tropis Kai-tak ada pada tingkat tropical storm.

Pada tanggal 17-22 Desember 2017, terlihat bahwa badai tropis Kai-tak telah melemah pada tingkat tropical depression.Hal ini menyebabkan jumlah massa uap air yang dibawa terus berkurang jika dibandingkan dengan jumlah massa uap air pada tingkat tropical storm.Namun jumlah massa uap air ini tetap mempengaruhi proses dinamika atmosfer di wilayah tersebut walaupun kecil, dimana pada saat tersebut bersamaan dengan adanya penjalaran massa udara dingin dari Asia. Bergabungnya dua massa uap air yaitu dari penjalaran massa udara Asia dan badai tropis Kai-tak kemudian membawa jumlah massa uap air pada kisaran 600- $1400 \mathrm{~kg} \mathrm{~m} / \mathrm{s}$. Jumlah massa uap air yang banyak yang terkandung pada awan-awan konvektif akan mengakibatkan awan menjadi berat dan perlahan-lahan daya tarik bumi menariknya kebawah. Hal inilah yang menyebabkan hujan turun sehingga memberikan peluang fenomena cuaca ekstrem di sebagian besar wilayah Indonesia. 


\subsection{Analisis Curah Hujan}

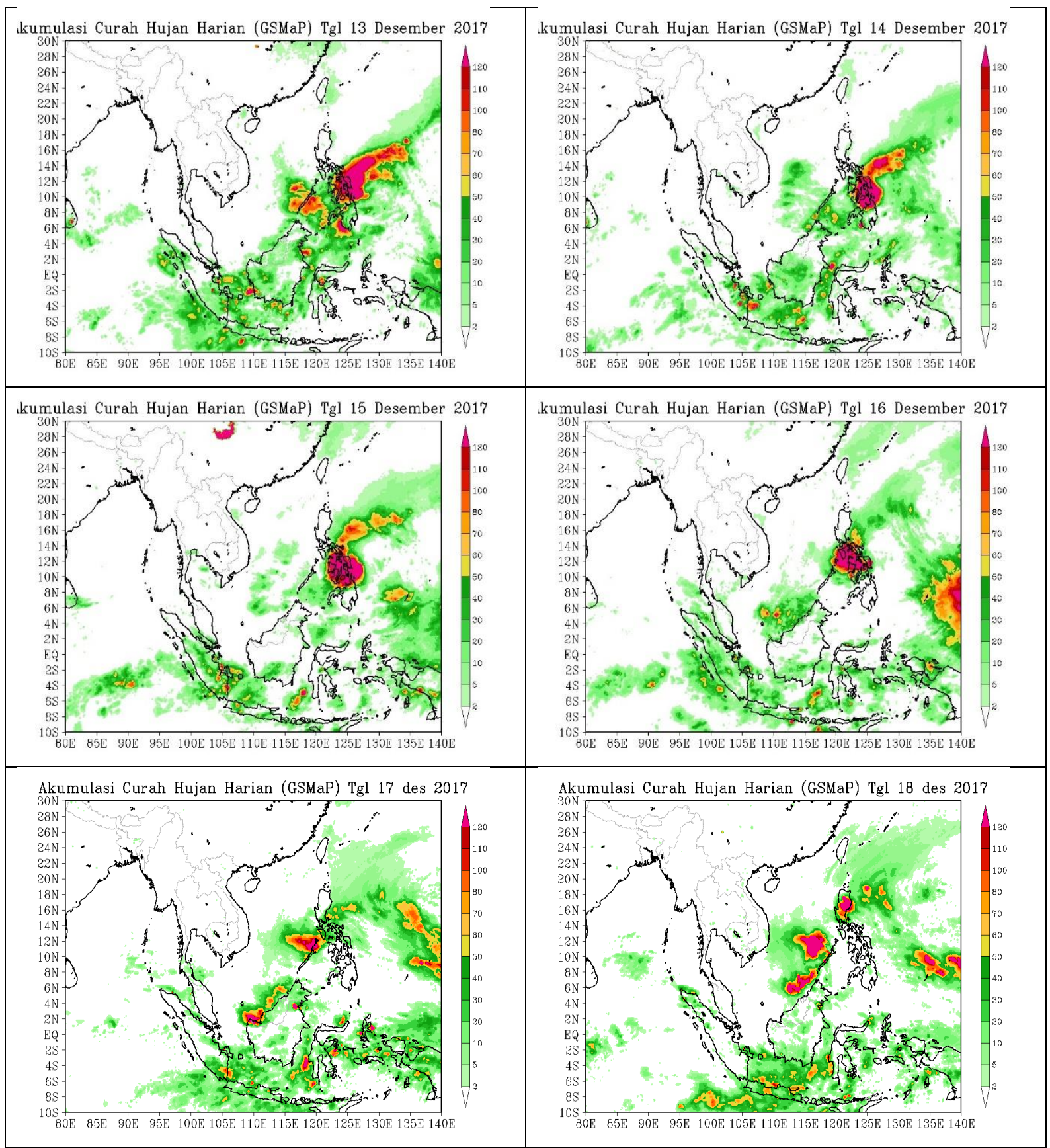




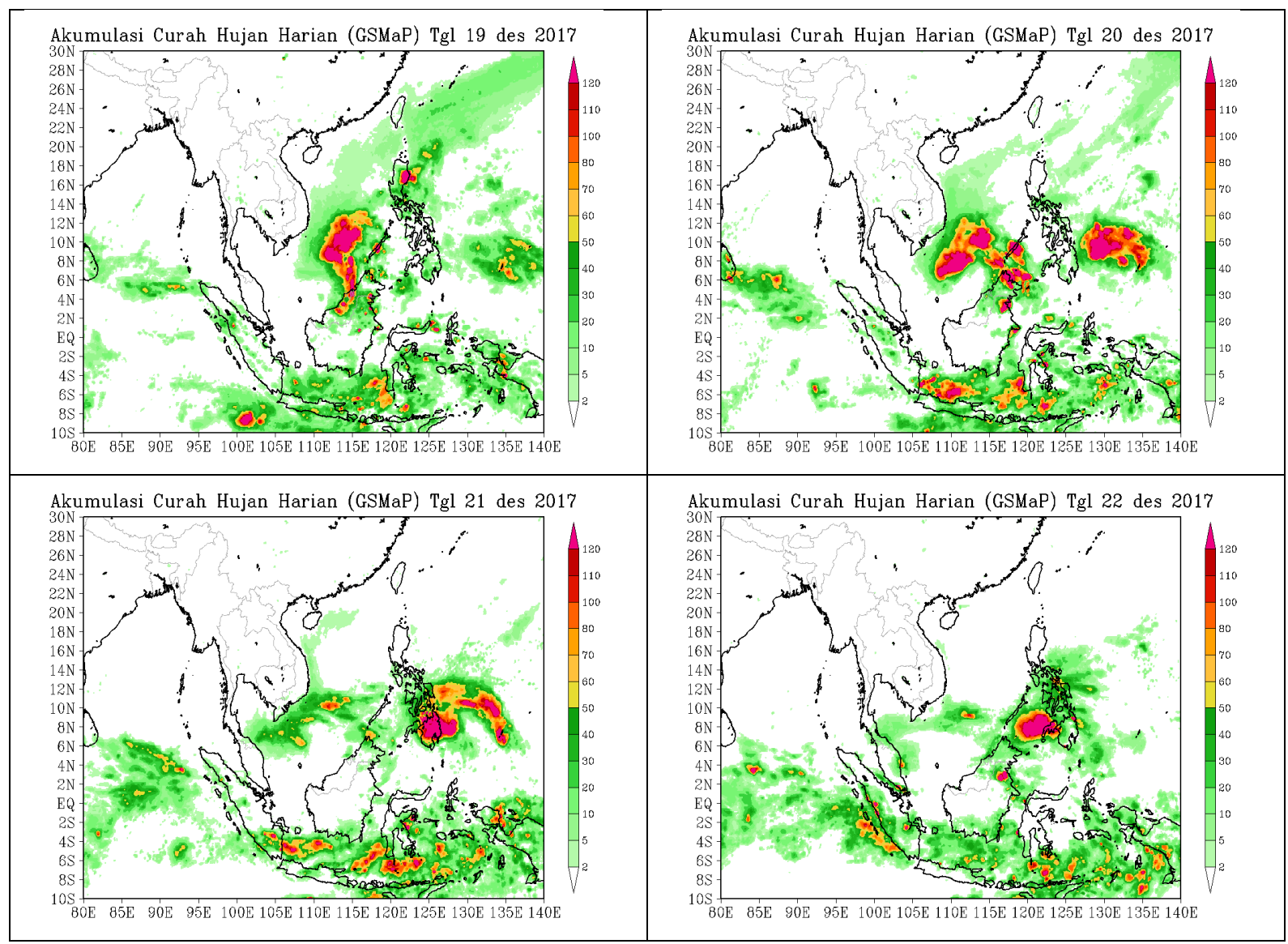

Gambar 5. Akumulasi curah hujan harian (GSMaP) saat kejadian badai tropis Kai-tak 17 22 Desember 2017

Hasil analisis spasial curah hujan harian pada tanggal 13 Desember 2017 sampai dengan tanggal 16 Desember 2017 menunjukkan bahwa terdapat intensitas curah hujan yang cukup tinggi di wilayah timur Filipina. Curah hujan dengan intensitas tinggi kemudian bergerak mengikuti awan konvektifnya (Gambar 3). Selain itu, terdapat hujan dengan intensitas 10-30 $\mathrm{mm}$ per hari didaerah sekitar adanya badai tropis Kai-tak. Daerah-daerah yang terkena dampak badai tropis Kai-tak ini diantaranya wilayah utara Pulau Kalimantan bagian timur,wilayah utara Pulau Sulawesi hingga wilayah utara Pulau Halmahera serta sebagian Sumatera bagian Selatan dan Pulau Jawa.

Pada tanggal 17-22 Desember 2017, terdapat intensitas curah hujan yang cukup tinggi di wilayah utara Pulau Kalimantan,serta terdapat pula intensitas hujan 10-40 mm per hari di sebagian besar wilayah Indonesia. Hal ini merupakan akibat dari dampak interaksi antara badai tropis Kai-tak dengan adanya penjalaran massa udara dari Asia. Namun pada kasus ini, dapat diidentifikasi bahwa hal ini lebih kuat terjadi karena pengaruh massa udara dari Asia daripada badai tropis Kai-tak yang pada saat periode itu ada pada tingkat tropical depression yang hampir punah,sehingga pengaruh badai tropis Kai-tak akan lebih kecil terhadap distribusi hujan di wilayah Indonesia . 


\section{KESIMPULAN}

Dari penelitian ini, dapat disimpulkan beberapa hal, yaitu sebagai berikut:

- Badai tropis Kai-tak terjadi pada periode 13-22 Desember 2017 dengan tingkat intensitas tropical storm pada tanggal 13-16 Desember 2017, dan tropical depression pada tanggal 1722 Desember 2017.

- Dari hasil analisis indeks konvektif menunjukkan pada saat badai tropis Kai-tak pada tingkat tropical storm (13-16 Desember 2017) terdapat nilai indeks konvektif yang tinggi berkisar antara 40-50 di wilayah timur perairan Filipina yang bergerak menuju wilayah utara pulau Kalimantan. Hal ini menandakan adanya aktivitas konvektif yang sangat tinggi di wilayah tersebut. Selain itu, badai tropis Kai-tak juga menyebabkan banyaknya pumpunan awan akibat adanya daerah konvergensi yang diakibatkan badai tropis Kai-tak dengan nilai indeks konvektif berkisar antara 20-40 di sebagian besar wilayah Indonesia.Pada tanggal 17-22 Desember 2017 nilai indeks konvektif akibat badai tropis Kai-tak nilainya terus menurun, namun pada saat yang sama ada penjalaran massa udara dari Asia sehingga di sebagian wilayah Indonesia tetap memiliki nilai indeks konvektif pada periode tersebut.

- Dari hasil analisis moisture transport menunjukkan bahwa terdapat nilai jumlah massa uap air yang sangat tinggi pada saat badai tropis Kai-tak ada pada tingkat tropical storm.Jumlah massa uap air dari badai tropis Kai-tak kemudian bergabung dengan jumlah masssa uap air yang dibawa oleh penjalaran massa udara dari Asia sehingga menyebabkan terbentuknya banyak awan-awan konvektif di sebagian besar wilayah Indonesia.

- Dari hasil analisis curah hujan, pada saat badai tropis Kai-tak ada pada tingkat tropical storm menyebabkan curah hujan dengan intensitas tinggi di wilayah Filipina (mengikuti pergerakan awan konvektif) serta hujan dengan intensitas $10-30 \mathrm{~mm}$ per hari pada wilayah utara Pulau Kalimantan bagian timur,wilayah utara Pulau Sulawesi hingga wilayah utara Pulau Halmahera serta sebagian Sumatera bagian Selatan dan Pulau Jawa.Kemudian pada saat badai tropis Kaitak melemah, curah hujan di sebagian besar wilayah Indonesia dipengaruhi lebih kuat oleh adanya penjalaran massa udara dari Asia.

\section{SARAN}

Dari penelitian ini, ada beberapa saran dalam melakukan penelitian terkait dengan dinamika atmosfer akibat adanya badai tropis yaitu sebagai berikut:

- Perlu diadakan lebih banyak lagi kajian tentang adanya pengaruh dari terbentuknya badai tropis yang tumbuh di sekitar wilayah Indonesia terhadap kondisi cuaca di wilayah Indonesia

- Perlu di adakannya analisis fisis kondisi atmosfer pada saat kejadian badai tropis.

- Dalam penelitian selanjutnya diharapkan untuk lebih mempertimbangkan analisis parameter cuaca dalam skala lokal seperti vertical divergensi atau vertical velocity. Hal ini akan sangat membantu menjelaskan proses dinamika atmosfer yang terjadi

\section{DAFTAR PUSTAKA}

BMKG, (2017), Siklon Hidup Siklon Tropis, Retrieved from http://meteo.bmkg.go.id/siklon/learn/03/id,

Nugraha.S.K.,(2016), Kajian Dampak Siklon Tropis Kirrily Terhadap Kondisi Cuaca di Maluku dan Papua Barat Pada Tanggal 26 - 29 April 2009. Skripsi: Program Studi Meteorologi Sekolah Tinggi Meteorologi Klimatologi dan Geofisika.

Rasyid.T.H.A.,(2016), Kajian Kondisi Atmosfer di Wilayah Indonesia Saat Kejadian Siklon Tropis In-fa dan Siklon Tropis Annabel (Tanggal 17- 27 November 2015) .Skripsi: Program Studi Meteorologi Sekolah Tinggi Meteorologi Klimatologi dan Geofisika. 
Sakurai, N., Murata, F., Yamanaka, M. D., Mori,S., Hamada,J.I., Hashiguchi,H., Tauhid, Y. I., Sribimawati, T., dan Suhardi, B., (2005), Diurnal cycle of cloud system migration over Sumatera Island. Journal of the Meteorological Society of Japan. Ser. II, 83(5), 835850

Saragih,I.J.A.,Aries, K.,Prabu, A.S.,Muhammad, P.R., (2018), Analisis Pola Transpor Uap Air di Indonesia Sebagai Dampak Terjadinya Siklon Tropis Cempaka dan Dahlia. Prosiding Siklon Tropis Peringatan 10 Tahun TCWC Jakarta,17-25

Sugianto, P.A., Ayu, I., Putra,R., Ahmad,F.,(2017), Distribusi Curah Hujan Sebagai Dampak Dari Fenomena Siklon Tropis Stan (27 Januari-1 Februari 2016) di Wilayah Makassar, Bima, Komodo, dan Cilacap. Prosiding Pekan Ilmiah Fisika Universitas Negeri Semarang 2017.

Xiaoxia, Z., Yihui, D., dan Panxing, W., (2010), Moisture Transpor in the Asian Summer Monsoon Region and Its Relationship with Summer Precipitation in China, Acta Meteorologica Sinica,24,31-42.

Zakir, A. dan M.K. Khotimah.(2006). Badai dan Pengaruhnya Terhadap Cuaca Buruk di Indonesia. Retrieved from http://meteo.bmkg.go.id/arsippdf/Badai Tropis.doc.

Zakir, Ahmad., Widada Sulistya dan Mia Khusnul Khotimah., (2010). Perspektif Operasional Cuaca Tropis. Jakarta, Jakarta: Badan Meteorologi Klimatologi dan Geofisika. 